\title{
FROM "WHITE CHRISTMAS" TO SGT. PEPPER: THE CONCEPTUAL REVOLUTION IN POPULAR MUSIC
}

\author{
David Galenson \\ Working Paper 13308 \\ http://www.nber.org/papers/w13308 \\ NATIONAL BUREAU OF ECONOMIC RESEARCH \\ 1050 Massachusetts Avenue \\ Cambridge, MA 02138 \\ August 2007
}

The views expressed herein are those of the author(s) and do not necessarily reflect the views of the National Bureau of Economic Research.

(C) 2007 by David Galenson. All rights reserved. Short sections of text, not to exceed two paragraphs, may be quoted without explicit permission provided that full credit, including $\odot$ notice, is given to the source. 
From "White Christmas" to Sgt. Pepper: The Conceptual Revolution in Popular Music

David Galenson

NBER Working Paper No. 13308

August 2007

JEL No. J01

\begin{abstract}
$\underline{\text { ABSTRACT }}$
Irving Berlin, Cole Porter, and other songwriters of the Golden Era wrote popular songs that treated common topics clearly and simply. During the mid-1960s Bob Dylan, John Lennon, and Paul McCartney created a new kind of popular music that was personal and often obscure. This shift, which transformed popular music from an experimental into a conceptual art, produced a distinct change in the creative life cycles of songwriters. Golden Era songwriters were generally at their best during their 30s and 40s, whereas since the mid-'60s popular songwriters have consistently done their best work during their 20s. The revolution in popular music occurred at a time when young innovators were making similar transformations in other arts: Jean-Luc Godard and his fellow New Wave directors created a conceptual revolution in film in the early '60s, just as Andy Warhol and other Pop artists made painting a conceptual activity.

David Galenson

Department of Economics

University of Chicago

1126 East 59th Street

Chicago, IL 60637

and NBER

galenson@uchicago.edu
\end{abstract}


$\underline{\text { Introduction }}$

Another birthday and you're almost in tears;

Another birthday and you're counting the years.

Irving Berlin, “Old Men”1

In 1942, Bing Crosby sang “White Christmas” in the movie Holiday Inn. The song became a hit in that year, spending ten weeks in first place on the Lucky Strike Hit Parade countdown, and it went on to become perhaps the most successful popular song ever written. Not only has Crosby's version sold more than 30 million copies, but "White Christmas” has been recorded by scores of other musicians, including Louis Armstrong, Frank Sinatra, Perry Como, Nat King Cole, Charlie Parker, Fats Domino, Elvis Presley, Aretha Franklin, the Beach Boys, the Supremes, the Jackson Five, Willie Nelson, Bob Dylan, Barbara Streisand, Bob Marley and the Wailers, and U2. ${ }^{2}$ Irving Berlin wrote both the lyrics and music for "White Christmas." When the song was released in 1942, he was 54 years old. ${ }^{3}$

In 2003, Rolling Stone magazine announced that a poll of 273 experts had named Sgt. Pepper's Lonely Hearts Club Band as the greatest rock and roll album ever made. The magazine’s music editor explained that “The Beatles, after all, were the most important and innovative rock group in the world. And Sgt. Pepper arguably set the tone for what an album could be.”4 Eleven of the songs on Sgt. Pepper were written by John Lennon and Paul McCartney, and one was written by George Harrison. When Sgt. Pepper was released in 1967, Lennon was 27 years old, McCartney was 25, and Harrison was 24.

The age difference of the writers of "White Christmas" and Sgt. Pepper is striking: Irving Berlin was twice as old as any of the Beatles when they produced their respective landmark works. This might be dismissed as an isolated anomaly. In fact, however, it wasn’t. During the 
mid-1960s, a revolution changed the nature of popular music. One consequence of this revolution was a dramatic change in the creative life cycles of the artists who write popular songs. This paper will describe how popular music was changed by this revolution, and will document the change in the life cycles of popular songwriters that accompanied the revolution.

\section{The Golden Era}

A simple melody will always linger -

I mean the kind you pick out with one finger.

Irving Berlin, “An Old-Fashioned

Tune is Always New"5

In his 1995 study of The American Popular Ballad of the Golden Era, 1924-1950, Allen Forte observed that the popular ballad was "usually sincere, earnest, and straightforward.” Lyricists avoided "the obscure, the esoteric, and any elements that would render the ballad inaccessible to the ideal patron," and made "a conscious effort to reach the average man and woman.”6 In their 2006 monograph, Classic American Popular Song, David Jenness and Don Velsey made similar comments. Thus they noted that "an invariable feature of the good song is that... the metrical fitting of words and phrases to a given melodic contour follows the natural prosody of spoken English,” and that the lyrics “are invariably in a familiar mode... They deal with common topics: either the experience that is common to all humans, or about topics that a generation or a group has in common.”7 In their 2006 book, America’s Songs, Philip Furia and Michael Lasser observed that "the song writers who gave us what has come to be known as the Great American Songbook were not writing about themselves; they were writing about us. They were democratic populists who gave voice to the American people.”

The songwriters of the Golden Era generally regarded themselves as craftsmen rather than artists, as they created "a professional tradition... based upon a relatively sophisticated 
command of music.”9 Their desire to write songs that reflected everyday life in their society without artistic pretentiousness was neatly expressed in a tribute paid by one great songwriter to another, as Jerome Kern wrote of Irving Berlin that "He doesn't attempt to stuff the public ears with pseudo-original, ultra modernism, but he honestly absorbs the vibrations emanating from the people, manners and life of his time, and in turn gives these impressions back to the world simplified - clarified - glorified. ${ }^{10}$ Berlin himself acknowledged the modest place of his genre in a lyric:

Popular song, you will never be missed, Once your composer has ceased to exist, While Chopin and Verdi, Beethoven and Liszt Live on with each generation. ${ }^{11}$

Forte observed that the classic popular song was "written exclusively in the vernacular."12 Late in his life, Berlin explained that he had always aimed to write "in the simplest way... as simple as writing a telegram." ${ }^{13}$ Berlin’s principal considerations in writing lyrics were “ease, naturalness, every-day-ness... 'Easy to sing, easy to say, easy to remember and applicable to everyday events' is a good rule for a phrase." ${ }^{\prime 4}$ Looking back on his own development, Cole Porter took pride in the fact that "My songs are easier than they used to be musically and lyrically." 15 Throughout his career, Porter's music was frequently described by critics as sophisticated, but he rejected their intended praise: “I’ve worked like a dog to keep all ['sophisticated'] implies out of my music.” He told an interviewer that what he really wanted was to write "genuine American folk songs."16

Alec Wilder observed that Irving Berlin "never deviated from his purpose of writing songs which stem from the music of the people, whether it be ragtime, swing music, country music, or the work of his contemporaries." ${ }^{17}$ Berlin wanted his music to reach everyone: "The 
mob is always right. It seems to be able to sense instinctively what is good, and I believe that there are darned few good songs which have not been whistled or sung by the crowd." ${ }^{18}$ His peers generally shared this attitude. So for example George Gershwin explained why he insisted on calling Porgy and Bess a folk opera rather than simply an opera: "I hoped to have developed something in American music that would appeal to the many rather than to the allured few."19 Richard Rodgers declared that "All I really want to do is to provide a hard-worked man in the blouse business with a method of expressing himself. If he likes a tune, he can whistle it, and it will make his life happier."20

The practices and attitudes of the Golden Era songwriters stemmed in large part from their recognition of the role of their work, for their songs were virtually always created in response to the needs of musical comedy scripts that had been written before the composers or lyricists ever became involved. From an early date, songwriters accepted as a test of quality that their songs should not disrupt the continuity of the play. Thus Jerome Kern told an interviewer that "It is my opinion that the musical numbers should carry on the action of the play, and should be representative of the personalities of the characters who sing them... In other words, songs must be suited to the action and the mood of the play."21 Furthermore, over time the degree of integration of the songs into the plot, and their role in developing characters, came to be considered increasingly important criteria for a songwriter's success. So for example Gerald Mast noted that "Dramatically, Porgy and Bess [1935], following the lead of Show Boat [1927] but building with absolute consistency on its example, defined a song or musical passage as a highly particularized expression of just that character just then just there. No American piece of musical theater had adhered so ruthlessly to this principle before Porgy and Bess; no major piece 
of American musical theater would retreat from it after Porgy and Bess.”22 Similarly, Geoffrey Block observed that "As early as the 1920s [Richard] Rodgers strove to create musicals in which songs were thoroughly integrated into the dramatic whole. In his finest efforts with [Lorenz] Hart, including On Your Toes [1936] and Pal Joey [1940], and in his first collaboration with [Oscar] Hammerstein, Oklahoma! [1943], Rodgers often succeeded in making the songs flow naturally from the dialogue and express character. But it was not until Carousel [1945] that Rodgers created a thoroughly unified musical score which also achieved a truly convincing coordination (i.e. integration) between music and dramatic action.”23 Hammerstein complimented his collaborator Rodgers by describing him as "essentially a composer for plays. He writes music to depict story and character and is, therefore, himself a dramatist. He is not an abstractionist in any sense and, as far as I can see, he has no interest in the mere creation of sound, however unusual or ingenious. He composes in order to make words fly higher or cut deeper than they would without the aid of his music."24

In addition to tailoring their songs to advance plots and develop characters, some Golden Era song writers produced songs intended for specific actors. A biographer of Cole Porter noted that as a Yale undergraduate, when Porter was writing the score for a fraternity musical, “Cole expressed to [the director] a practice he retained all his life: 'Tell me whom you select for different parts, and I can write fitting songs the more easily.' "25 Many years later, the star actress Ethel Merman noted that one of Porter's most famous songs was an example of this: "What Cole had done was to analyze my voice and turn out songs which showed off its variety. 'You're the Top’ brought audiences to their feet because it was a new kind of love song."26 More generally, William Zinsser observed that during 1935-38, Irving Berlin, Jerome Kern, Dorothy Fields, and 
George and Ira Gershwin all wrote some of their finest songs for the actor Fred Astaire: "They knew that whatever they wrote, he would sing it perfectly, every note true, every syllable clear, every nuance of emotion and humor caught with natural elegance and timing and taste. Knowing this, they stretched their wings and reached a high level of freshness and artistry."27

Golden era songwriters were experimental artists. This is witnessed by both the form and the substance of their work, as they used informal, vernacular language clearly and simply to treat common topics, familiar to a wide audience, in a realistic and convincing way. Thus a biographer of Irving Berlin tellingly compared his most famous masterpiece to the greatest work of a great experimental poet: “As a song, 'White Christmas' is the counterpart to Robert Frost's great modern poem, 'Stopping by Woods on a Snowy Evening,' which uses the simplest of rhymes and the barest of imagery to evoke a beautiful but melancholy scene.”28 The Golden Era songwriters' experimental approach is equally reflected in the modesty and diffidence with which they approached their work, for their unwillingness to claim the status of artist was a result of their perception that they were not autonomous, but rather made up only one part of a larger genre: for them songwriting was not an end in itself, but was done in the service of musical comedy. The greatest of the Golden Era songwriters took plots and characters designed by others, and brought them to life with music and lyrics carefully created to complement them. Like many other experimental artists, these songwriters therefore denied they were artists at all, claiming instead that they were highly skilled professional craftsmen.

\section{The Conceptual Revolution}

Dylan was a revolutionary. Bob freed your mind the way Elvis freed your body. He showed us that just because the music was innately physical did not mean that it was anti-intellectual... He invented a new way a pop singer could sound, broke through the 
limitations of what a recording artist could achieve and changed the face of rock and roll forever.

Bruce Springsteen, $1988^{29}$

Picture yourself in a boat on a river, With tangerine trees and marmalade skies.

John Lennon and Paul McCartney, "Lucy in the Sky With Diamonds," $1967^{30}$

The emergence of rock and roll in the 1950s separated popular music from musical comedies, as more songs were written in order to be performed by individual singers or groups. Yet the experimental nature of popular songwriting did not change in the early years of rock and roll, as professional songwriters continued to use vernacular language and simple images to treat common ideas and emotions. Elvis Presley and other important early figures in rock and roll were celebrated as performers, but continued to sing songs written by professional writers. Thus the critic James Miller observed that "In the early Sixties, it was customary for rock and roll acts to record songs written by somebody else. That, after all, is how Elvis Presley had done it. It was how the music business had been run for a century. Songwriters wrote, and singers sang - a division of labor that helped to maintain a certain (often minimal) standard of professionalism.”31

This situation changed during the 1960s, as a revolution occurred in popular music. Within a few years in the middle of the decade, popular songwriting was transformed from an experimental to a conceptual art. This not only changed the locus of the creation of popular songs, as professional songwriters were replaced by singer-songwriters, but it also changed the form and substance of popular music. Today, more than four decades later, the conceptual approach to popular songwriting remains the dominant one.

Although there were many contributors to the revolution, three men - Bob Dylan and the 
team of John Lennon and Paul McCartney - were clearly recognized as the leaders at the time, and their legacy continues to dominate popular music today. The influence and conceptual nature of their art have made these musicians the subject of a vast amount of criticism and scholarship, and numerous studies of their work effectively describe the revolution. Thus the music scholar John Covach observed that "Lennon and McCartney begin their careers aspiring to be songwriters in the American Pop tradition, and accordingly they view themselves as craftspeople, using formal designs and arrangements schemes that are common to much of 1960s pop.” A transition began in 1964: "the space between 1964 and 1967 is an important time in pop music's developing sense of aspiration in general... [T] he change from pop songwriters to songwriting artists occurs gradually in the Lennon-McCartney songs from that period.” At the end of the transition, “Sgt. Pepper's Lonely Hearts Club Band makes its mark as the album that ... elevates rock music from simple dance fare to serious listening music. Rock musicians no longer aspire so much to be professionals and craftspeople; rather, they aspire to be artists.”32

The art in question was to be conceptual. James Miller described the change in the nature of the Beatles' music during this period of transition: “Up till then, rock and roll had been primarily a music of revelry, a medium for lifting people up and helping them dance their blues away. Under the combined influence of marijuana and Bob Dylan's unkempt persona, the Beatles would turn it into something else again: a music of introspective self-absorption, a medium fit for communicating autobiographical intimacies, political discontents, spiritual elation, inviting an audience, not to dance, but to listen - quietly, attentively, thoughtfully."33 Dylan's music was changing at the same time, in a similar way, as he was becoming a conceptual artist even more deliberately and self-consciously. Thus Miller noted that in 1964 
Dylan recorded a number of new songs that "featured unromantic and sometimes inscrutable lyrics that were involuted, hermetic, yet seething with an undefined, faintly intoxicating sense of self-righteous rage.” Within a year, under the inspiration of a conceptual young genius of the nineteenth century, he had transformed his music: "A poet and a prophet, he would write out of his own life, with no apparent regard for the pieties prevailing in society. In the spirit of Rimbaud, he would make himself a 'seer by a long, gigantic and rational derangement of the senses,' ... and concentrating the force of his personal revelations in a music of delirious immediacy.” ${ }^{34}$ Mark Polizzotti remarked that "Lyrically, Rimbaud’s influence is palpable in what Dylan termed his 'vision music,' songs that defy conventional definition to create a powerfully suggestive ambient landscape... But even more than this, Rimbaud... shows through the attitude underlying these songs: young, street-smart, arrogant, rebellious, and highly seductive. ${ }^{35}$

In place of the earlier experimental popular music that treated familiar subjects clearly and simply, from 1964 on Dylan and the Beatles created a new, conceptual popular music that was complex and often incomprehensible. The critic Mike Marqusee noted that "As you listen to [Dylan's albums of 1964-66], the images, characters, tropes sail past in a strange ether. They're experienced as free-floating metaphors, signifiers uprooted from the signified. These songs often feel like allegories but they cannot be decoded as such.”36 The critic David Hajdu explained that in this music Dylan "was not pursuing refinement, sophistication, and clarity of expression, those ideals of the Cole Porter generation of songwriters, but their near opposites: kinetic energy, instinct, and ambiguity... He was making rock and roll a modern art, a form of idiosyncratic, frequently obtuse personal expression." ${ }^{37}$ 
Conceptual artists innovate by creating unexpected syntheses of earlier art forms, and this is precisely what Dylan and the Beatles did during the mid-60s. Marqusee described the remarkably wide variety of Dylan’s influences: "Drawing on folk, blues, country, R \& B, rock’n'roll, gospel, British beat, symbolist, modernist and Beat poetry, surrealism and Dada, advertising jargon and social commentary, Fellini and Mad magazine, he forged a coherent and original artistic voice and vision.” Marqusee noted that Dylan’s use of literary sources emphasized range over depth: “Apart from the Beats, Dylan’s reading was sporadic and undisciplined, but he was a magpie, and even a casual acquaintance with Eliot, cummings, the French symbolists, and the surrealists left traces in his work. For all the strident populism, Dylan in this period is without a doubt a self-conscious, avant-garde artist.” And Marqusee observed that Dylan plundered the musical past as irreverently as an earlier conceptual innovator had plundered the history of poetry: "in reality, the breach between Dylan and the musical traditions he drew on was as qualitative as the breach that separated the modernists from their sources... Recorded music enabled Dylan to ransack the American musical heritage like Ezra Pound at loose in a library of medieval manuscripts.”38 In 1966, when Robert Shelton asked Dylan if his songs were influential because he broke the rules, Dylan responded, “I don’t break the rules, because I don't see any rules to break. As far as I’m concerned, there aren’t any rules.”39 Dylan has testified to his youthful ambition to create a revolution. In his recent autobiography, he recalled his admiration for another earlier conceptual innovator: "Picasso had fractured the art world and cracked it wide open. He was revolutionary. I wanted to be like that." ${ }^{40}$ Dylan went about creating revolutionary work in a distinctive way, intended to draw on his subconscious. Hajdu described his method of composing during his peak years: "He laid out 
dozens of photographs torn from newspapers and magazines in a montage on the floor and sat down amidst them with his guitar... [H]e would close his eyes - he would not draw from the pictures literally but would use the impression the faces left as a visual model for kaleidoscopic language. He appeared to sing whatever came to him, disconnected phrases with a poetic feeling. When something came out that he liked, he scrawled it down hurriedly, so as to stay in the moment, and he would do this until there were enough words written for a song.” To stimulate his imagination, "he chain-smoked marijuana while he composed this work."41

Dylan had an enormous impact on the Beatles. John Lennon explained that Dylan’s music caused him to change his attitude toward writing songs: "I think it was Dylan helped me realize that - not by any discussion or anything but just by hearing his work - I had a sort of professional songwriter's attitude to writing pop songs ... But to express myself I would write ... the personal stories which were expressive of my personal emotions. I'd have a separate songwriting John Lennon who wrote songs for the sort of meat market, and I didn't consider them - the lyrics or anything - to have any depth at all. They were just a joke. Then I started being me about the songs, not writing them objectively, but subjectively."42 Lennon also explained that he directly emulated Dylan's drug-induced lyrics, as for example he recalled that in 1967 "I was writing obscurely, à la Dylan, never saying what you mean, but giving the impression of something. Where more or less can be read into it. It's a good game, I thought, They get away with this artsy-fartsy crap; there has been more said about Dylan's wonderful lyrics than was ever in the lyrics at all. Mine, too. But it was the intellectuals who read all this into Dylan or the Beatles. Dylan got away with murder. I thought, Well, I can write this crap, too. You know, you just stick a few images together, thread them together, and you call it 
poetry.” Lennon acknowledged that his new approach hadn’t been entirely cynical, but he stressed it was his own voice: "Well, maybe it is poetry. But I was just using the mind that wrote In His Own Write [the book he had published in 1964].” Like Dylan, Lennon borrowed freely from earlier literature: "I am the Walrus," for example, written in 1967, drew on sources as disparate as Shakespeare, Lewis Carroll, and Allen Ginsberg. ${ }^{43}$ In that year, the critic Robert Christgau remarked that the genius of the Beatles lay in their ability simultaneously to speak for themselves and to appeal to a vast audience, explaining that "A good Lennon-McCartney song is sufficiently cryptic to speak to the needs of whoever listens." ${ }^{44}$

The Beatles not only used hallucinogenic drugs in creating their new work, but also drew on increasingly complex recording technology in novel ways. The group sang their last live concert in August of 1966, and later that year they began to record music that could not have been made outside a recording studio. James Miller notes that "spurred on by a variety of startling new albums, including Blonde on Blonde by Bob Dylan, Pet Sounds by the Beach Boys, and Fifth Dimension by the Byrds, [Lennon and McCartney] were... single-mindedly dedicated to making the most mind-boggling album in the history of rock and roll." ${ }^{25}$ They succeeded, in the summer of 1967 releasing Sgt. Pepper's Lonely Hearts Club Band, which Rolling Stone magazine described in 2005 as "the most important rock and roll album ever made, an unsurpassed adventure in concept, sound, songwriting, cover art and studio technology by the greatest rock and roll group of all time.”46

An example of the novelty of the technical production of the new work is afforded by the creation of what was initially intended to be the album's first track, a Lennon composition titled "Strawberry Fields Forever." After the group had recorded two very different versions of the 
song, Miller recounted that Lennon was torn between the two: "Unable to choose, he blithely instructed [producer George] Martin to splice the two together. As a trained musician, Martin was flabbergasted. 'Brilliant,' he shot back. 'There are only two things wrong with that: the takes are in two different keys, a whole tone apart; and they have wildly different tempos.'” Lennon, however, was not fazed: “He had a relatively short attention span, and... wasn’t especially eager to learn more about the technical details involved in making, and appreciating, a complicated piece of music.” In the face of Lennon’s insistence, Martin went to work with his engineers: “The staff rigged up a Rube Goldberg contraption to vary the frequency of the tape playback. Luck was with them. By dropping the speed and pitch of the orchestral version, and speeding up the slower version... they were able to splice the two together.” The result was surprising to all involved: "Presto! Nearly four weeks and more than fifty-five hours [of studio time] after they had begun, the Beatles had produced a new piece of music. And even George Martin had to admit that the result was impressive. With pride, he once described 'Strawberry Fields' as 'a complete tone poem - like a modern Debussy." „47

In Miller’s account, “Strawberry Fields” is a classic example of a conceptual innovation made by young, inexperienced artists who are concerned with creating new art forms and have little regard for, or knowledge of, traditional rules and constraints: their inexperience can effectively liberate them from conventions that constrain more experienced, or more respectful, artists. The composer and critic Ian MacDonald observed that "Here, the Beatles show that technical shortcomings, far from constraining the imagination, can let it expand into areas inaccessible to the trained mind. Heard for what it is - a sort of technologically evolved folk music - 'Strawberry Fields Forever' shows expression of a high order. While there are countless 
contemporary composers qualified to write music hugely more sophisticated in form and technique, few if any are capable of displaying feeling and fantasy so direct, spontaneous, and original." ${ }^{\text {8 }}$ George Martin, who had formal training in classical music, agreed: "I think that if Paul [McCartney] , for instance, had learned music 'properly' - not just the piano, but correct notation for writing and reading music, all the harmony and counterpoint that I had to go through, and techniques of orchestration - it might well have inhibited him... Once you start being taught things, your mind is channelled in a particular way. Paul didn’t have that channelling, so he had freedom, and could think of things that I would have considered outrageous. I could admire them, but my musical training would have prevented me from thinking of them myself." ${ }^{29}$

Computer analysis of changes in the lyrics of the Beatles' albums over time supports the accounts offered by music critics of the conceptual revolution in their music during the mid-' 60 s. So for example although the songs of Sgt. Pepper contain only 13\% more total words than the songs on the 1964 album A Hard Day's Night, overall the songs of Sgt. Pepper contain more than 75\% more different words than those of Hard Day’s Night. And as the vocabulary expanded, so did the topics treated. Thus for example the word "love," which occurs 53 times in the lyrics of Hard Day's Night, occurs only 13 times in those of Sgt. Pepper. Based on their analysis of the nine albums the Beatles made from 1964 through 1970, Guy Cook and Neil Mercer concluded that "the later songs use a much wider range of vocabulary. This reflects the fact that the writers were dealing with more varied topics and moving beyond the conventional vocabulary of rock and roll., ${ }^{50}$

The innovations of Dylan, Lennon, and McCartney quickly spread and reverberated 
throughout popular music. An example is afforded by Brian Wilson, who had felt the challenge of the Beatles as early as 1963, when Meet the Beatles prompted him to tell his cousin and fellow Beach Boy Mike Love, “We’ve got to grow, go beyond the formula." 51 But it was late in 1965, when Wilson heard Rubber Soul, that he formulated a new goal for his music: “The album blew my mind because it was a whole album with all good stuff. It was definitely a challenge for me. I saw that every cut was very artistically interesting and stimulating.” He later recalled that “I really wasn’t quite ready for its unity." 52 After a prayer session in which Brian and his brother Carl prayed for an album that would be better than Rubber Soul, Brian set out "to make a complete statement." 53 Just months later the result was Pet Sounds, which eventually came to be recognized as Wilson's masterpiece, and one of the most important albums of the rock era. ${ }^{54}$ Wilson described the album as “the single-minded pursuit of a personal vision. I wasn’t just entertaining people, I was speaking directly to them, directly from my heart." ${ }^{55}$ In addition to its introspective lyrics that treated personal and often painful themes, in Pet Sounds Wilson introduced a number of musical innovations, including novel chord progressions and complex vocal arrangements, that dismayed not only many of the Beach Boys’ fans, but also the group’s other members. Irritated by the difficulty of recording the vocals, Mike Love protested, “Who’s gonna hear this? The ears of a dog?"56 But Pet Sounds had an almost immediate impact on other musicians, including notably the Beatles. Paul McCartney declared it "the album of all time," and he often played it during breaks from the recording of Sgt. Pepper, as a challenge to him and the other Beatles to equal it. ${ }^{57}$ Brian Wilson’s recording led Paul to ask Geoff Emerick, the Beatles' chief engineer, for a “really clean American sound” on "Penny Lane,” and Emerick responded by changing his normal technique, recording each instrument by itself so there would 
be no leakage, and each instrument would be heard more clearly. ${ }^{58}$

Irving Berlin and his fellow professional song writers contemptuously dismissed Dylan and the Beatles as "unprofessionals." ${ }^{59}$ Yet the very qualities that the skilled experimental songwriters of the Golden Era derided as amateurish were prized by the conceptual young singer-songwriters as the secret to their success. When an interviewer in 1986 referred to the epoch-making work he had done in the mid-‘60s, Dylan responded, "I did that accidentally.” In 1991, when an interviewer asked how he wrote songs, Dylan remarked that he had never seriously considered it a profession: "It's been more confessional than professional." ${ }^{\text {60 }}$ And in his autobiography, Dylan recalled that when he was first starting out in New York, "Nothing would have convinced me that I was actually a songwriter and I wasn't, not in the conventional songwriter sense of the word. Definitely not like the workhorses over in the Brill Building, the song chemistry factory... [T]hey were the songwriting masters of the Western world, wrote all the popular songs, all the songs with crafty melodies and simple lyrics that came off as works of power over the airwaves. ${ }^{\circ 1}$ Dylan's denials that he was a professional songwriter did not imply that he didn’t take his work seriously, however. In a 1977 interview he declared that he was doing what he was doing because "I’m good at it.” When asked what "it” was, he replied, “I’m an artist. I try to create art.”62 James Miller argued that the unprofessional approach pioneered by Dylan and the Beatles became characteristic of the best rock music, which offers "the sound of surprise: not the surprise of virtuosos improvising new ways to play (the thrill of jazz), but rather the surprise of untrained amateurs, working within their limits, finding a voice of their own - and sometimes even elaborating new song forms unthinkable to more highly skilled musicians.”33 The Life Cycles of Great Popular Songwriters 
[U]nlike every other great genre of American pop, rock is all about being young.

$$
\text { James Miller }{ }^{64}
$$

Earlier studies have found that the life cycles of experimental and conceptual innovators in a number of different arts differ considerably, as experimental artists tend to make their most important contributions later in their careers than their conceptual counterparts. ${ }^{65}$ The preceding sections of this paper have argued that popular songwriting changed from an experimental to a conceptual art during the mid-1960s. The task for this study is to determine whether the life cycles of songwriters changed accordingly. Specifically, the general analysis of creative life cycles would predict that important songwriters of the Golden Era would have made their greatest contributions later in their careers than leading songwriters of the conceptual era that was initiated by Bob Dylan and the Beatles. Empirical evaluation of this prediction will be done in two stages; the first will examine the timing of the careers of important Golden Era songwriters, and the second will do the same for important popular songwriters from the mid‘60s on.

Three authoritative surveys can be used both to identify the most important songwriters of the Golden Era and to determine when they produced their most important works. These three surveys are: 1) a ranking of the 100 most-recorded songs written in the first half of the $20^{\text {th }}$ century; 2) a ranking of the 30 “all-time favorite songs,” based on a 1953 national survey of disc jockeys by Billboard magazine; and 3) Variety magazine’s listing of the “Golden 100 Tin Pan Alley Songs.” $" 66$ The most important songwriters of the Golden Era were identified from these three sources, as the sum of all the individuals who were in the following groups: all writers who had two or more songs among the top 40 songs in source (1) above; all writers who had two or 
more songs in source (2); and the 10 writers who had the most songs listed in source (3).

This selection process yielded a total of 14 songwriters, who are listed in Table 1 . The process was designed to identify the greatest songwriters of the Golden Era, and it clearly does include those writers who have been judged most important by authoritative studies of the subject. Thus the listing includes the only six writers - Jerome Kern, Irving Berlin, Cole Porter, George Gershwin, Richard Rodgers, and Harold Arlen - who were given individual chapters in Alec Wilder’s American Popular Song: The Great Innovators, 1900-1950; these six are also the only writers who received individual chapters in Allen Forte's The American Popular Ballad of the Golden Era, 1921-1950. Forte referred to these writers collectively as the "Big Six." Although no distinction will be made in the quantitative analysis between composers and lyricists, it might be noted that six of the sample members were composers (Arlen, Duke, George Gershwin, Kern, McHugh, and Rodgers), six were lyricists (Fields, Ira Gershwin, Hammerstein, Harbach, Hart, and Mercer), and two were both (Berlin and Porter).

The same three surveys can be used to identify these songwriters’ most important works. Appendix Table 1 lists all the songs among the top 40 in source (1) that were written by members of the sample constructed for this paper. There are 17 songs in the table, and these yield a total of 25 observations on songwriters' ages when the songs were created. These observations are summarized in an age distribution in Table 2.

Appendix Table 2 lists all the songs from source (2) written by sample members. The 13 songs in the table yield 21 observations on songwriters' ages when these songs were written. These observations are summarized as an age distribution in Table 2.

Appendix Table 3 lists all the songs from source (3) written by sample members. The 47 
songs yield 71 observations on songwriters' ages. These are again summarized in a distribution in Table 2.

Examining Table 2 as a whole, the three different sources produce very similar results. In all three samples, the age group with the most entries is the 30s, as this decade accounts for more than $40 \%$ of the entries in all three samples. And in all the samples, in each case with more than $25 \%$ of the entries, the second most important age group is the 40 s. The 20 s is the third most important age group in two of the samples, and ties for third place in one; in none of the three samples does this decade account for more than $21 \%$ of the entries.

In all three samples, at least $79 \%$ of the entries are for ages 30 and above. And in all three samples, there were far more entries for ages 40 and above than for ages below 30. Table 2 thus indicates that the greatest song writers of the Golden Era were most likely to be in their 30s when they wrote their greatest songs. When this was not the case, they were more likely to be in their 40s than in their 20s when they did their best work.

Two large and authoritative surveys provide quantitative evidence on the best songs of the era of rock and roll. One is a ranking of VH1's 100 Greatest Albums, published in 2003, based on a poll of more than 700 musicians, songwriters, disc jockeys, radio programmers, and critics. ${ }^{68}$ The second is a ranking of Rolling Stone's 500 Greatest Albums of All Time, published in 2005, as selected by a panel of 273 voters, including singers, songwriters, musicians, producers, record executives, artist managers, and critics. ${ }^{69}$

Consideration of the VH1 and Rolling Stone rankings immediately underscores a fundamental change that was part of the conceptual revolution in popular music, namely a shift from the individual song to the album as the key product: all three of the earlier surveys took 
individual songs as their focus, whereas both of the later rankings assumed that albums were the proper unit of observation. These units are so obvious to those who conducted the surveys that in no case is the choice of the unit of observation discussed in the source. The Beatles' producer, George Martin, recalled that when the group released Rubber Soul in 1965, "For the first time we began to think of albums as art on their own, as complete entities." ${ }^{70}$ From then on, the most important popular music would generally be recorded not as stand-alone single songs, but as collections of songs that were linked by a concept or style. So for example in 1967 the Beatles would present a landmark album made up of "a suite of songs loosely linked by autobiographical themes as well as the conceit that they were all being performed by a fictional group, Sgt. Pepper’s Lonely Hearts Club Band."71

Appendix Table 4 lists the best five albums from each of four decades - the '60s through the '90s - as ranked by VH1. The songwriters listed are all those who received writing credits and for whom birthdates could be identified. The competition for places in this table for the 1960s was particularly intense: the five top albums of that decade are ranked among the greatest eight albums of all time. While the Beatles occupy three of the decade's five entries for the decade, Dylan fails to qualify, for his highest-rated album ranks ninth overall. In total, the 20 albums in Appendix Table 4 yield 58 observations on songwriters' ages. These are summarized in an age distribution in Table 3.

Appendix Table 5 lists the best five albums from each of the decades from the '60s through the ' 90 s as ranked by Rolling Stone. Here the Beatles again fill three of the five slots from the '60s, with Sgt. Pepper in first place, and Dylan has one entry in each of the two decades of the '60s and '70s. Overall, there is considerable agreement between the VH1 and Rolling 
Stone rankings, as half of all the albums in Tables 4 and 5 appear in both tables. In total, the 20 albums of Appendix Table 5 yield 63 observations on songwriters' ages; these are summarized in an age distribution in Table 3.

Before examining the ages of the songwriters, it might be noted that Appendix Tables 4 and 5 provide strong support for an aspect of the conceptual revolution noted earlier. Thus in every case - in all the albums listed in the two tables - the songwriters were also the performers who recorded the songs. This would come as no surprise to critics, for as Martin Goldsmith explained, this became a necessary element of success after the conceptual revolution: "Before the Beatles came along, pop musicians rarely sang their own songs; neither Frank Sinatra nor Elvis Presley was a composer. After the Beatles, groups were expected to perform their own material; relying exclusively on cover songs was a sure sign of a second-rate band.”72

The age distributions of Table 3 present a clear contrast to those of Table 2. The age group of the 20s dominates both distributions in Table 3; 76\% of the writers in the first distribution, and $68 \%$ in the second, were in their 20s. In both distributions the second most important decade is the 30s, but in neither case does it account for as much as one third as many observations as the 20s. And in neither case do songwriters over 40 account for more than $11 \%$ of the total observations. The evidence of Table 3 thus clearly indicates that from the ' 60 s on, the most important popular songs were overwhelmingly written by songwriters below the age of 30 . Age and the Popular Songwriter

When you're young, you're probably writing stronger and a lot quicker.

Bob Dylan, 2001

Although there has been little discussion of why the ability to write excellent popular 
songs tended to increase with age among Golden Era writers, a number of scholars and critics have noted that it clearly did in particular cases. So for example Allen Forte remarked that “A complete study of [Irving] Berlin’s songs would have to take into account the very early songs, some of which are indescribably bad - for example 'My Harem'” (1914) [when Berlin was 26]. It is difficult to believe that this was written by the Irving Berlin of 'White Christmas.",74 Robert Kimball observed that "Between 1916 and 1928 [ages 25-37]... [Cole] Porter struggled to find his own voice. It was his friend, Irving Berlin, who told him one of his problems was that he was trying to write like other people instead of his own style."75 And Alec Wilder wrote that he "was astonished to find in [Jerome] Kern’s early work only capable, professional, but uninspired songs... in no way indicative of what was to come.” Wilder in fact believed that "had [Kern] not grown in style and invention [after the age of 29] he would not be remembered today. And more than that, even when he did become a sophisticated, memorable writer, he still continued to change."76

As discussed earlier, Golden Era songwriters generally contended that they were craftsmen rather than artists, and they made considerable efforts to avoid appearing pretentious or self-absorbed. One consequence of this was that they rarely made introspective statements. Their infrequent evaluations of their own careers tended to be short and pithy. So for example late in his life Irving Berlin commented on his own early songs that "I call'em bad. They were not only bad, they were amateurish."77 A rare extended statement about why a Golden Era writer improved with age was made by the composer Richard Rodgers in a posthumous tribute to his long-time collaborator Lorenz Hart: “It seems to me that Larry’s later lyrics were of higher degree of excellence than his early ones and that they achieved this through a growing maturity 
of their own. Later on he seemed almost to substitute warmth for wit, and while he really didn't know how not to be clever, he began to show off less and to be more concerned with emotion. 'Where or When,' for instance, had much of the philosophical in it and I can think of no lyric more touched with tenderness than 'Funny Valentine.' In the face of the pin-wheel brilliance of some of Larry’s work, one is inclined to forget the deeper phases of his writing." 78

Probably even less attention has been devoted to the general question of why the greatest popular music has been written by the young in the past four decades. In a 1984 press conference, Paul McCartney conceded that "I would have to admit for myself, looking at all the songs I’ve written, probably there’s a period in there that was my hottest, 'Yesterday' [1965], 'Here, There and Everywhere’ [1966]. There’s a bunch of stuff that all came during a few years and I suppose it was because we were at our height and the novelty of it was a very important factor." 79

Bob Dylan has made a number of comments about his changing abilities, in part because interviewers have frequently raised the issue of his decline. In 1984, referring to his work of the ‘60s, Dylan told an interviewer that “I can’t write those songs today. No way. But I look at those songs, 'cause I sing 'em all the time, I wonder where they came from and how they came... I couldn't do them now, and I don’t even try, I'd be a fool to try.” In 1997 he told a reporter that “I’ve written some songs that I look at, and they just give me a sense of awe. Stuff like 'It's Alright, Ma’ [1965], just the alliteration in that blows me away. And I can also look back and know... where I was really saying something that just happened to have a spark of poetry to it.” In 2001, Dylan tried to describe how he had written "Like a Rolling Stone,” but conceded that he couldn’t: “It's like a ghost is writing a song like that. It gives you the song and it goes away, it 
goes away. You don't know what it means. Except the ghost picked me to write the song." 80 Dylan gave a more extended treatment of this theme in his autobiography, within an account of a visit he made to New Orleans in 1989 to work with a prominent producer, Daniel Lanois, in the hope of reviving his recording career. Dylan recalled that as they worked together, Lanois would say to him 'We need songs like 'Masters of War,' 'Girl from the North Country,' or 'With God on Our Side’ [all 1963].” Dylan just nodded in response: “I didn’t have anything like those songs." Eventually, Lanois gave up. "I would have liked to been able to give him the kinds of songs that he wanted, like 'Masters of War,' 'Hard Rain’ [1963], 'Gates of Eden’ [1965], but those kinds of songs were written under different circumstances, and circumstances never repeat themselves. Not exactly. I couldn't get to those kinds of songs for him or anyone else. To do it, you've got to have power and dominion over the spirits. I had done it once, and once was enough. Someone would come along eventually who would have it again - someone who could see into things, the truth of things - not metaphorically, either - but really see, like seeing into metal and making it melt, seeing it for what it was and reveal it for what it was with hard words and vicious insight." ${ }^{\prime 1}$ In contrast to one aspect of these statements, however, in which Dylan professes not to understand why his creativity had diminished, in 1995 he explained that age, and conscious attention to invention, interfered with his particular gift: “As you get older, you get smarter and that can hinder you because you try to gain control over the creative impulse... If your mind is intellectually in the way, it will stop you." ${ }^{82}$

Experimental artists' work tends to improve with age, as they gain a greater understanding both of life - their subject- and of their art. Thus Richard Rodgers believed Lorenz Hart’s lyrics improved as Hart gained greater self-confidence and emotional maturity. 
Conceptual artists' work tends to deteriorate with age, as they lose the freshness of their early approach, and become constrained by acquired habits of thought. Thus the aging Paul McCartney looked back to the novelty of writing hits in the early years of the Beatles, and Bob Dylan could only look back with regret and awe at the powerful imagery he had created in his youth.

$\underline{\text { Conclusion }}$

We shall always be too busy delineating characters in our plays to spend very much time on ourselves. A good thing, too.

Oscar Hammerstein, on his collaboration with Richard Rodgers, $1951^{83}$

My songs were written with me in mind.

Bob Dylan, $1991^{84}$

During the first half of the twentieth century, American popular songwriters developed a professional tradition. The best of these writers, individually or in teams, combined fluent and often witty use of vernacular language with a sophisticated knowledge of music. Their best songs expressed universal emotions simply and clearly, with melodies that were easy to learn and remember.

A handful of artists transformed popular music during a brief period in the mid-1960s. The leaders of this revolution created a new kind of popular music that was neither simple nor clear. Complex verbal images were often combined with new recording technologies to make songs that eluded precise interpretation. These songs typically expressed the attitudes and emotions of the artists who wrote them.

Golden Era songwriters wrote songs to fit the needs of musical comedies. Their songs were intended to advance the plots of these productions, and to develop their characters. These 
songs were written to be sung by professional actors, and might even be tailored to the personalities and abilities of specific singers. In contrast, Bob Dylan, the Beatles, and other leading popular songwriters of the '60s and beyond wrote for themselves. They performed their own songs, which were typically autobiographical in nature. Their work privileged imagination and fantasy over description and realism.

Dylan, the Beatles, and other rock musicians created a conceptual revolution. The popular songwriting of the Golden Era had been an experimental art, at its best based on highly skilled work by experienced practitioners. During the mid-‘60s, a new breed of songwriter invented a conceptual popular music, in which a relative lack of musical training and experience allowed radical departures from traditional conventions and practices. This revolution changed the face of popular music, as singer-songwriters became the rule in an art that had previously been based on a strict division of labor between writers and performers. And as the music became more personal, new forms of behavior emerged. So for example like conceptual innovators in other arts, popular singers began deliberately to create new identities for themselves: "Dylan, as precursor to all the self-conscious self-inventors of pop, employed his identity masks willfully: shockingly but not exactly spontaneously. It hardly detracts from Dylan's greatness to suggest that each new shift was the result of calculation as much as any ‘natural’ artistic progression... It was a perverse and innovative strategy for pop.”85

This study has shown that the creative life cycles of Golden Era songwriters differed significantly from those of the new conceptual songwriters. The most important Golden Era songwriters were generally at their best during their 30s and 40s. In contrast, Dylan, Lennon, and McCartney were the first among scores of important songwriters of the past four decades who 
have done their greatest work in their 20s.

It is interesting that the sharp drop in the creativity of aging rock songwriters has often been noted in particular cases, including notably those of Dylan, Lennon, and McCartney. Many explanations have been offered for these dramatic declines. Yet these explanations have invariably been specific to the individual artists in question. In contrast, this study has offered a general explanation. The loss of creativity with age suffered by Dylan, Lennon, McCartney, and so many of their successors as they have aged is not a phenomenon caused by factors unique to these individuals, or even to rock music. Instead, these artists appear to be prime examples of the loss of conceptual creativity with age, one of the most powerful and pervasive patterns in human creativity.

\section{Coda: Beyond Popular Music}

I think the Beatles are working in the same way I make movies... The Beatles and the Rolling Stones are very important because they are popular and intellectual at the same time... That is what I am trying to do in movies.

Jean-Luc Godard, $1968^{86}$

The conceptual revolution in popular music did not occur in isolation, for young innovators were making similar transformations of a number of other arts: thus Jean-Luc Godard and his fellow New Wave directors created a conceptual revolution in film in the early '60s, just as Andy Warhol and other Pop artists turned painting into a conceptual activity. ${ }^{87}$ What is particularly interesting about these conceptual revolutions is how durable they have been, for conceptual innovators have tended to dominate all of these arts throughout the intervening decades. It is possible that this durability is in all these cases due to a common internal dynamic, which has two elements. One of these is the growing public appreciation of conspicuous and 
dramatic innovation, which produces a heightened demand for new forms in each of these arts, and raises the rewards for novel contributions. The second is the glamor associated with these activities, which produces a large supply of potential innovators. These elements have combined in these arts to create regimes in which conceptual approaches, that can quickly yield new results, have been preeminent. These arts have consequently been characterized by a steady flow of new ideas, produced by a succession of young artists who typically make a single novel contribution early in their careers. ${ }^{88}$ Understanding the conceptual revolution in popular music may therefore do more than heighten our recognition of the importance of Bob Dylan and the Beatles, for it may also help us to appreciate the growing importance of conceptual innovation more generally in our society. 


\section{Footnotes}

I thank Joshua Kotin for discussions.

1. $\quad$ Rosen 2002, 169.

2. $\quad$ Mast 1987, 39; Rosen 2002, 6-7.

3. The song was probably written in 1940; Rosen 2002, Chap. 2.

4. Gunderson 2003.

5. $\quad$ Rosen 2002, 17.

6. Forte 1995, 28-29.

7. Jenness and Velsey 2006, 9-10.

8. $\quad$ Furia and Lasser 2006, xxvi.

9. Wilder 1972, xxxvi; also Rosen 2002, 182; Furia and Lasser 2006, xxvi.

10. Woollcott 1925, 215.

11. Jablonski 1999, 66.

12. Forte 1995, 28.

13. Rosen 2002, 4.

14. Furia 1998, 43.

15. McBrien 1998, 364.

16. McBrien 1998, 200.

17. Wilder 1972, 119.

18. Furia 1998, 194.

19. Wyatt and Johnson 2004, 218.

20. Block 2002, 201.

21. Boardman 1980, 149-50.

22. Mast 1987, 85. 
23. Block 1997, 170-71.

24. Block 2002, 81.

25. McBrien 1998, 45.

26. McBrien 1998, 171.

27. Zinsser 2000, 103.

28. Furia 1998, 204. On Frost as an experimental poet, see Galenson 2006a, 159-60.

29. Hedin 2004, 203.

30. MacDonald 2005, 240.

31. $\quad$ Miller 1999, 195.

32. Womack and Davis 2006, 38-39.

33. Miller 1999, 227-28.

34. Miller 1999, 221, 227. On Rimbaud as a conceptual poet, see Galenson 2006a, 216-18.

35. Polizzotti 2006, 39.

36. $\quad$ Marqusee 2003, 138.

37. Hajdu 2001, 234, 280.

38. Marqusee 2003, 131, 151. On Pound as a conceptual poet, see Galenson 2006a, 158.

39. Shelton 1986, 344.

40. Dylan 2004, 55. On Picasso as a conceptual artist, see Galenson 2006a, 11-13.

41. Hajdu 2001, 233-34.

42. Wenner 1971, 126.

43. Golson 2000, 184-85.

44. Sawyers 2006, 118.

45. Miller 1999, 253.

46. Levy 2005, 9. 
47. Miller 1999, 254-55; also see Everett 1999, Chap. 2; Martin 1979, 214.

48. MacDonald 2005, 220.

49. Martin 1979, 139.

50. Cook and Mercer 2000, 99-100.

51. Lambert 2007, 147.

52. Lambert 2007, 224.

53. Lambert 2007, 224; White 1994, 252.

54. Pet Sounds ranked second in the Rolling Stone poll referred to above, and third in a VH1 poll of the greatest rock albums; Levy 2005, 12-13; Hoye 2003, 6-9.

55. Lambert 2007, 223.

56. Gaines 1995, 146.

57. MacDonald 2005, 215; Emerick 2006, 142.

58. Emerick 2006, 142.

59. Rosen 2002, 182.

60. Cott 2006, 336, 384.

61. Dylan 2004, 227.

62. Ricks 2005, 11.

63. Miller 1999, 19.

64. Miller 1999, 19.

65. E.g. see Galenson 2006a.

66. Whitburn 1986, 632-33; Hamm 1979, 489-92.

67. Forte 1995, 4.

68. Hoye 2003, xv.

69. Levy 2005, 7, 218-19. 
70. Miller 1999, 230.

71. Miller 1999, 256; also see Moore 1997, 72,

72. Goldsmith 2004, 169.

73. Cott 2006, 427

74. Forte 1995, 87. Ten different songs by Berlin appear in Appendix Tables 1-3. Only one of these was written before the age of 30 .

75. McBrien 1998, 75. Six different songs by Porter appear in Appendix Tables 1-3. All were written when he was 38 or older.

76. Wilder 1972, 32-33. Five different songs by Kern appear in Appendix Tables 1-3. All were written when he was 40 or older.

77. Jablonski 1999, 290.

78. Block 2002, 268.

79. Giuliano and Devi 1999, 103.

80. $\quad$ Cott 2006, 317, 396, 432.

81. Dylan 2004, 195, 218-19.

82. Ricks 2005, 8.

83. Block 2002, 82.

84. Cott 2006, 381.

85. McKinney 2003, 107. For a parallel in another conceptual art, see Galenson 2006b.

86. $\quad$ Sterritt 1998, 15.

87. Cowie 2004; Galenson 2001, Chap. 7.

88. Galenson 2006a, Chap. 8; Galenson and Kotin, 2007. 
Table 1: Most Important Songwriters of the Golden Era.

\begin{tabular}{|l|c|c|}
\hline & Year of birth & Year of death \\
\hline \hline Arlen, Harold & 1905 & 1986 \\
\hline Berlin, Irving & 1888 & 1989 \\
\hline Duke, Vernon & 1903 & 1969 \\
\hline Fields, Dorothy & 1905 & 1974 \\
\hline Gershwin, George & 1898 & 1937 \\
\hline Gershwin, Ira & 1896 & 1983 \\
\hline Hammerstein, Oscar & 1895 & 1960 \\
\hline Harbach, Otto & 1873 & 1963 \\
\hline Hart, Lorenz & 1895 & 1943 \\
\hline Kern, Jerome & 1885 & 1945 \\
\hline McHugh, Jimmy & 1894 & 1969 \\
\hline Mercer, Johnny & 1909 & 1976 \\
\hline Porter, Cole & 1892 & 1964 \\
\hline Rodgers, Richard & 1902 & 1979 \\
\hline
\end{tabular}

Source: see text and Appendix Tables 1-3. 
Table 2: $\quad$ Distributions of Ages of Golden Era Songwriters When They Wrote Their Most Important Works

\begin{tabular}{|l|c|c|c|c|c|c|}
\hline \multicolumn{1}{|c|}{ Source: } & \multicolumn{2}{|c|}{$(1)$} & \multicolumn{2}{c|}{$(2)$} & \multicolumn{2}{c|}{$(3)$} \\
\hline Ages & $\mathrm{n}$ & $\%$ & $\mathrm{n}$ & $\%$ & $\mathrm{n}$ & $\%$ \\
\hline \hline $20-9$ & 3 & 12 & 1 & 5 & 15 & 21 \\
\hline $30-9$ & 11 & 44 & 11 & 52 & 29 & 41 \\
\hline $40-9$ & 7 & 28 & 7 & 33 & 19 & 27 \\
\hline $50-9$ & 2 & 8 & 1 & 5 & 7 & 10 \\
\hline $60-9$ & 2 & 8 & 1 & 5 & 1 & 1 \\
\hline Total & 25 & 100 & 21 & 100 & 71 & 100 \\
\hline
\end{tabular}

Sources: See text for discussion. For data, see:

(1) Appendix Table 1.

(2) Appendix Table 2.

(3) Appendix Table 3. 
Table 3: Age Distributions of Rock Songwriters When They Wrote Their Most Important Works

\begin{tabular}{|l|c|c|c|c|}
\hline \multicolumn{1}{|c|}{ Source: } & \multicolumn{2}{|c|}{ VH1 Ranking } & \multicolumn{2}{c|}{ Rolling Stone Ranking } \\
\hline Ages & $\mathrm{n}$ & $\%$ & $\mathrm{n}$ & $\%$ \\
\hline \hline $20-9$ & 44 & 76 & 43 & 68 \\
\hline $30-9$ & 10 & 17 & 13 & 21 \\
\hline $40-9$ & 3 & 5 & 6 & 10 \\
\hline $50-9$ & 1 & 2 & 1 & 1 \\
\hline $60-9$ & 0 & 0 & 0 & 0 \\
\hline Total & 58 & 100 & 63 & 100 \\
\hline
\end{tabular}

Source: see text and Appendix Tables 4-5. 


\section{Bibliography}

Block, Geoffrey. 1997. Enchanted Evenings. New York: Oxford University Press.

Block, Geoffrey, ed. 2002. The Richard Rodgers Reader. Oxford: Oxford University Press.

Boardman, Gerald. 1980. Jerome Kern. New York: Oxford University Press.

Cook, Guy, and Neil Mercer. 2000. "From Me to You: Austerity to Profligacy in the Language of the Beatles.” In Ian Inglis, ed., The Beatles, Popular Music and Society. New York: St. Martin’s Press, pp. 86-104.

Cott, Jonathan, ed. 2006. Bob Dylan: The Essential Interviews. New York: Wenner.

Cowie, Peter. 2004. Revolution! The Explosion of World Cinema in the Sixties. New York: Faber and Faber.

Dylan, Bob. 2004. Chronicles: Volume One. New York: Simon and Schuster.

Emerick, Geoff. 2006. Here, There and Everywhere. New York: Gotham Books.

Everett, Walter. 1999. The Beatles as Musicians. New York: Oxford University Press.

Forte, Allen. 1995. The American Popular Ballad of the Golden Era, 1924-1950. Princeton: Princeton University Press.

Furia, Philip. 1998. Irving Berlin. New York: Schirmer.

Furia, Philip, and Michael Lasser. 2006. America’s Songs. New York: Routledge.

Gaines, Steven. 1995. Heroes and Villains. New York: Da Capo Press.

Galenson, David. 2001. Painting Outside the Lines. Cambridge: Harvard University Press.

Galenson, David. 2006a. Artistic Capital. New York: Routledge.

Galenson, David. 2006b. "You Cannot be Serious: The Conceptual Innovator as Trickster." NBER Working Paper 12599.

Galenson, David, and Joshua Kotin. 2007. "From the New Wave to the New Hollywood: The Life Cycles of Movie Directors from Godard and Truffaut to Spielberg and Eastwood." Unpublished paper, University of Chicago.

Giuliano, Geoffrey, and Vrnda Devi. 1999. Glass Onion. New York: Da Capo Press.

Goldsmith, Martin. 2004. The Beatles Come to America. Hoboken, New Jersey: John Wiley and 
Sons.

Golson, G., ed. 2000. All We Are Saying. New York: St. Martin’s Griffin.

Gunderson, Edna. 2003. “It’s certainly a thrill: 'Sgt. Pepper’ is best album.” USA Today, Nov. 11.

Hajdu, David. 2001. Positively $4^{\text {th }}$ Street. New York: North Point.

Hamm, Charles. 1979. Yesterdays. New York: W. W. Norton.

Hedin, Benjamin, ed. Studio A: The Bob Dylan Reader. New York: W. W. Norton.

Hoye, Jacob, ed. 2003. VH1's 100 Greatest Albums. New York: Barnes and Noble.

Jablonski, Edward. 1999. Irving Berlin. New York: Henry Holt.

Jenness, David, and Don Velsey. 2006. Classic American Popular Song. New York: Routledge.

Lambert, Philip. 2007. Inside the Music of Brian Wilson. New York: Continuum.

Levy, Joe, ed. 2005. Rolling Stone: The 500 Greatest Albums of All Time. New York: Wenner.

MacDonald, Ian. 2005. Revolution in the Head. second revised ed. London: Pimlico.

Marqusee, Mike. 2003. Chimes of Freedom. New York: New Press.

Martin, George. 1979. All You Need Is Ears. New York: St. Martin’s Press.

Mast, Gerald. 1987. Can’t Help Singin’. Woodstock: Overlook Press, 1987.

McBrien, William. 1998. Cole Porter. New York: Alfred A. Knopf.

McKinney, Devin. 2003. Magic Circles. Cambridge: Harvard University

Miller, James. 1999. Flowers in the Dustbin. New York: Simon and Schuster.

Moore, Allan. 1997. The Beatles: “Sgt. Pepper’s Lonely Hearts Club Band.” Cambridge: Cambridge University Press.

Polizzotti, Mark. 2006. Highway 61 Revisited. New York: Continuum.

Ricks, Christopher. 2005. Dylan’s Visions of Sin. New York: Ecco.

Rosen, Jody. 2002. White Christmas. New York: Scribner. 
Sawyers, June. 2006. Read the Beatles. New York: Penguin.

Shelton, Robert. 1986. No Direction Home. New York: William Morrow.

Sterritt, David, ed. 1998. Jean-Luc Godard Interviews. Jackson: University Press of Mississippi.

Wenner, Jann. 1971. Lennon Remembers. San Francisco: Straight Arrow Books.

Whitburn, Joel. 1986. Pop Memories, 1890-1954. Menomonee Falls, WI: Record Research.

White, Timothy. 1994. The Nearest Faraway Place. New York: Henry Holt.

Wilder, Alec. 1972. American Popular Song. New York: Oxford University Press.

Womack, Kenneth, and Todd Davis, eds. 2006. Reading the Beatles. Albany: State University of New York Press.

Woollcott, Alexander. 1925. The Story of Irving Berlin. New York: G. P. Putnam’s Sons.

Wyatt, Robert, and John Johnson, eds. 2004. The George Gershwin Reader. Oxford: Oxford University Press.

Zinsser, William. 2001. Easy to Remember. Jaffrey, NH: David R. Godine. 
Appendix Table 1: $\quad$ Ages of Sample Members When They Wrote Songs Ranked Among the 40 Most- Recorded, 1890-1954

\begin{tabular}{|c|c|c|c|}
\hline Rank & Song & Writer(s) & Age \\
\hline 5 & “Summertime” & G. Gershwin & 37 \\
\hline 8 & “White Christmas” & Berlin & 54 \\
\hline 9 & "All the Things You Are" & $\begin{array}{l}\text { Kern } \\
\text { Hammerstein }\end{array}$ & $\begin{array}{l}54 \\
44\end{array}$ \\
\hline 10 & "Night and Day" & Porter & 40 \\
\hline 11 & "Begin the Beguine" & Porter & 43 \\
\hline 14 & “The Man I Love” & $\begin{array}{l}\text { G. Gershwin } \\
\text { I. Gershwin }\end{array}$ & $\begin{array}{l}26 \\
28\end{array}$ \\
\hline 15 & “Over the Rainbow” & Arlen & 34 \\
\hline 18 & “Yesterdays” & $\begin{array}{l}\text { Kern } \\
\text { Harbach }\end{array}$ & $\begin{array}{l}48 \\
60\end{array}$ \\
\hline 20 & “Lover, Come Back to Me” & Hammerstein & 33 \\
\hline 21 & “What Is This Thing Called Love?” & Porter & 38 \\
\hline 22 & “I Can’t Get Started” & $\begin{array}{l}\text { Duke } \\
\text { I. Gershwin }\end{array}$ & $\begin{array}{l}33 \\
40\end{array}$ \\
\hline 24 & “I Can’t Give You Anything But Love” & $\begin{array}{l}\text { McHugh } \\
\text { Fields }\end{array}$ & $\begin{array}{l}34 \\
23\end{array}$ \\
\hline 28 & “Blue Skies” & Berlin & 39 \\
\hline 31 & “Always” & Berlin & 37 \\
\hline 35 & “Smoke Gets In Your Eyes” & $\begin{array}{l}\text { Kern } \\
\text { Harbach }\end{array}$ & $\begin{array}{l}48 \\
60 \\
\end{array}$ \\
\hline 37 & “Ol’ Man River” & $\begin{array}{l}\text { Kern } \\
\text { Hammerstein }\end{array}$ & $\begin{array}{l}43 \\
33\end{array}$ \\
\hline 40 & “Embraceable You” & $\begin{array}{l}\text { G. Gershwin } \\
\text { I. Gershwin }\end{array}$ & $\begin{array}{l}32 \\
34\end{array}$ \\
\hline
\end{tabular}

Source: Whitburn 1986, 632. 
Appendix Table 2: $\quad$ Ages of Sample Members When They Wrote Songs Ranked Among 30 All-Time Favorites by Billboard

\begin{tabular}{|l|l|l|l|}
\hline Rank & Song & Writer(s) & Age \\
\hline \hline 5 & "Begin the Beguine” & Porter & 43 \\
\hline 6 & "Laura” & Mercer & 36 \\
\hline 9 & "Night and Day" & Porter & 40 \\
\hline 10 & "Blue Moon” & Rodgers & 33 \\
& & Hart & 40 \\
\hline 12 & "Lover" & Rodgers & 30 \\
& & Hart & 37 \\
\hline 13 & "I Can't Get Started” & Duke & 33 \\
& & I. Gershwin & 40 \\
\hline 15 & "That Old Black Magic” & Arlen & 37 \\
& & Mercer & 33 \\
\hline 17 & "I'm in the Mood for Love" & McHugh & 41 \\
& & Fields & 30 \\
\hline 19 & "Smoke Gets in Your Eyes" & Kern & 48 \\
& & Harbach & 60 \\
\hline 20 & "Embraceable You” & G. Gershwin & 32 \\
& & I. Gershwin & 34 \\
\hline 21 & "Always" & Berlin & 37 \\
\hline 24 & "White Christmas” & Berlin & 54 \\
\hline 26 & "On the Sunny Side of the Street” & McHugh & 36 \\
& & Fields & 25 \\
\hline
\end{tabular}

Source: Whitburn 1986, 639. 
Appendix Table 3: $\quad$ Ages of Sample Members When They Wrote Songs Listed in Variety Magazine's “Golden 100”

\begin{tabular}{|c|c|c|}
\hline Song & Writer(s) & Age \\
\hline “Alexander’s Ragtime Band” & Berlin & 23 \\
\hline “All Alone” & Berlin & 36 \\
\hline “All the Things You Are” & $\begin{array}{l}\text { Hammerstein } \\
\text { Kern }\end{array}$ & $\begin{array}{l}44 \\
54\end{array}$ \\
\hline “Always” & Berlin & 37 \\
\hline "A Pretty Girl is Like a Melody" & Berlin & 31 \\
\hline “April in Paris” & Duke & 29 \\
\hline "Begin the Beguine" & Porter & 43 \\
\hline "Bewitched, Bothered, and Bewildered” & $\begin{array}{l}\text { Hart } \\
\text { Rodgers }\end{array}$ & $\begin{array}{l}46 \\
39\end{array}$ \\
\hline “Blue Moon” & $\begin{array}{l}\text { Hart } \\
\text { Rodgers }\end{array}$ & $\begin{array}{l}39 \\
32\end{array}$ \\
\hline "Blues in the Night" & $\begin{array}{l}\text { Mercer } \\
\text { Arlen }\end{array}$ & $\begin{array}{l}32 \\
36\end{array}$ \\
\hline "Come Rain or Come Shine" & $\begin{array}{l}\text { Mercer } \\
\text { Arlen }\end{array}$ & $\begin{array}{l}37 \\
41\end{array}$ \\
\hline “Easter Parade” & Berlin & 45 \\
\hline “Exactly Like You” & $\begin{array}{l}\text { Fields } \\
\text { McHugh }\end{array}$ & $\begin{array}{l}25 \\
36 \\
\end{array}$ \\
\hline “Get Happy” & Arlen & 25 \\
\hline “God Bless America” & Berlin & 51 \\
\hline "How Deep is the Ocean?” & Berlin & 44 \\
\hline "I Can’t Give You Anything but Love” & $\begin{array}{l}\text { Fields } \\
\text { McHugh }\end{array}$ & $\begin{array}{l}23 \\
34\end{array}$ \\
\hline "I Get a Kick Out of You” & Porter & 42 \\
\hline "I Got Rhythm” & $\begin{array}{l}\text { I. Gershwin } \\
\text { G. Gershwin }\end{array}$ & $\begin{array}{l}34 \\
32\end{array}$ \\
\hline
\end{tabular}


Appendix Table 3, continued

\begin{tabular}{|c|c|c|}
\hline "I'm in the Mood for Love" & $\begin{array}{l}\text { Fields } \\
\text { McHugh }\end{array}$ & $\begin{array}{l}30 \\
41\end{array}$ \\
\hline "It Might as Well be Spring” & $\begin{array}{l}\text { Hammerstein } \\
\text { Rodgers }\end{array}$ & $\begin{array}{l}50 \\
43\end{array}$ \\
\hline "I've Got the World on a String" & Arlen & 28 \\
\hline “I’ve Got you Under My Skin” & Porter & 44 \\
\hline “Just One of Those Things” & Porter & 43 \\
\hline “Lover” & $\begin{array}{l}\text { Hart } \\
\text { Rodgers }\end{array}$ & $\begin{array}{l}38 \\
31\end{array}$ \\
\hline "Lover Come Back to Me" & Hammerstein & 33 \\
\hline "Marie" & Berlin & 40 \\
\hline "My Funny Valentine” & $\begin{array}{l}\text { Hart } \\
\text { Rodgers }\end{array}$ & $\begin{array}{l}42 \\
35\end{array}$ \\
\hline “My Heart Stood Still” & $\begin{array}{l}\text { Hart } \\
\text { Rodgers }\end{array}$ & $\begin{array}{l}32 \\
25\end{array}$ \\
\hline "Night and Day" & Porter & 40 \\
\hline "Old Black Magic” & $\begin{array}{l}\text { Mercer } \\
\text { Arlen }\end{array}$ & $\begin{array}{l}33 \\
37\end{array}$ \\
\hline “Ol’ Man River” & $\begin{array}{l}\text { Hammerstein } \\
\text { Kern }\end{array}$ & $\begin{array}{l}32 \\
42\end{array}$ \\
\hline "On the Sunny Side of the Street” & $\begin{array}{l}\text { Fields } \\
\text { McHugh }\end{array}$ & $\begin{array}{l}25 \\
36\end{array}$ \\
\hline "Over the Rainbow" & Arlen & 34 \\
\hline “Smoke Gets in Your Eyes” & $\begin{array}{l}\text { Harbach } \\
\text { Kern }\end{array}$ & $\begin{array}{l}60 \\
48\end{array}$ \\
\hline "Somebody Loves Me" & G. Gershwin & 26 \\
\hline "Some Enchanted Evening” & $\begin{array}{l}\text { Hammerstein } \\
\text { Rodgers }\end{array}$ & $\begin{array}{l}54 \\
47\end{array}$ \\
\hline “Stormy Weather” & Arlen & 28 \\
\hline "Summertime" & G. Gershwin & 37 \\
\hline
\end{tabular}


Appendix Table 3, continue

\begin{tabular}{|l|l|c|}
\hline “Swanee” & G. Gershwin & 21 \\
\hline “'S Wonderful” & I. Gershwin & 31 \\
& G. Gershwin & 29 \\
\hline “The Man I Love” & I. Gershwin & 28 \\
& G. Gershwin & 26 \\
\hline “What is This Thing Called Love” & Porter & 38 \\
\hline "White Christmas" & Berlin & 54 \\
\hline "Who?” & Harbach & 52 \\
& Hammerstein & 30 \\
& Kern & 40 \\
\hline “With a Song in My Heart” & Hart & 34 \\
& Rodgers & 27 \\
\hline “You'll Never Walk Alone" & Hammerstein & 50 \\
& Rodgers & 43 \\
\hline
\end{tabular}

Source: Hamm 1979, 489-92. 
Appendix Table 4: $\quad$ Ages at Which Songwriters Wrote Most Important Albums, by Decade, VH1 Rankings

\begin{tabular}{|c|c|c|c|}
\hline Rank & Artist, Album & Writer(s) & Age \\
\hline \multicolumn{4}{|c|}{$1960 \mathrm{~s}$} \\
\hline 1 & Beatles, Revolver & $\begin{array}{l}\text { Lennon } \\
\text { McCartney } \\
\text { Harrison }\end{array}$ & $\begin{array}{l}26 \\
24 \\
23\end{array}$ \\
\hline 2 & Beach Boys, Pet Sounds & $\begin{array}{l}\text { B. Wilson } \\
\text { Asher } \\
\text { Love } \\
\text { Sachen }\end{array}$ & $\begin{array}{l}24 \\
26 \\
25 \\
24\end{array}$ \\
\hline 3 & $\begin{array}{l}\text { Jimi Hendrix Experience, Are You } \\
\text { Experienced? }\end{array}$ & $\begin{array}{l}\text { Hendrix } \\
\text { Roberts }\end{array}$ & $\begin{array}{l}25 \\
31\end{array}$ \\
\hline 4 & Beatles, Rubber Soul & $\begin{array}{l}\text { Lennon } \\
\text { McCartney } \\
\text { Harrison }\end{array}$ & $\begin{array}{l}25 \\
23 \\
22\end{array}$ \\
\hline 5 & Beatles, Abbey Road & $\begin{array}{l}\text { Lennon } \\
\text { McCartney } \\
\text { Harrison } \\
\text { Starr }\end{array}$ & $\begin{array}{l}29 \\
27 \\
26 \\
29\end{array}$ \\
\hline \multicolumn{4}{|c|}{$\underline{1970 s}$} \\
\hline 1 & Marvin Gaye, What's Going On & $\begin{array}{l}\text { Benson } \\
\text { M. Gaye } \\
\text { Nyx } \\
\text { Stover } \\
\text { A. Gaye }\end{array}$ & $\begin{array}{l}35 \\
32 \\
57 \\
33 \\
49\end{array}$ \\
\hline 2 & Stevie Wonder, Songs In the Key of Life & Wonder & 26 \\
\hline 3 & Rolling Stones, Exile on Main Street & $\begin{array}{l}\text { Jagger } \\
\text { Richards } \\
\text { Taylor } \\
\text { Harpo }\end{array}$ & $\begin{array}{l}29 \\
29 \\
24 \\
48\end{array}$ \\
\hline 4 & The Who, Who's Next & $\begin{array}{l}\text { Townshend } \\
\text { Entwhistle }\end{array}$ & $\begin{array}{l}26 \\
27\end{array}$ \\
\hline 5 & Joni Mitchell, Blue & Mitchell & 28 \\
\hline
\end{tabular}


(Appendix Table 4, continued)

\begin{tabular}{|c|c|c|c|}
\hline \multicolumn{4}{|c|}{$\underline{1980 \mathrm{~s}}$} \\
\hline 1 & U2, Joshua Tree & $\begin{array}{l}\text { Bono } \\
\text { Clayton } \\
\text { Edge } \\
\text { Mullen }\end{array}$ & $\begin{array}{l}27 \\
27 \\
26 \\
26\end{array}$ \\
\hline 2 & Prince and the Revolution, Purple Rain & Prince & 26 \\
\hline 3 & $\begin{array}{l}\text { Public Enemy, It Takes a Nation of Millions to } \\
\text { Hold Us Back }\end{array}$ & $\begin{array}{l}\text { Chuck D } \\
\text { Sadler } \\
\text { Flavor Flav } \\
\text { Rodgers } \\
\text { Griffin }\end{array}$ & $\begin{array}{l}28 \\
27 \\
29 \\
22 \\
28\end{array}$ \\
\hline 4 & Michael Jackson, Thriller & $\begin{array}{l}\text { Jackson } \\
\text { Temperton } \\
\text { Bettis } \\
\text { Porcaro } \\
\text { Ingram } \\
\text { Jones } \\
\end{array}$ & $\begin{array}{l}24 \\
33 \\
36 \\
25 \\
26 \\
49 \\
\end{array}$ \\
\hline 5 & Prince, Sign "O" the Times & Prince & 29 \\
\hline \multicolumn{4}{|c|}{$\underline{1990 \mathrm{~s}}$} \\
\hline 1 & Nirvana, Nevermind & $\begin{array}{l}\text { Cobain } \\
\text { Grohl } \\
\text { Novoselic }\end{array}$ & $\begin{array}{l}24 \\
22 \\
26\end{array}$ \\
\hline 2 & Lauryn Hill, The Miseducation of Lauryn Hill & Hill & 23 \\
\hline 3 & U2, Achtung Baby & $\begin{array}{l}\text { Bono } \\
\text { Clayton } \\
\text { Edge } \\
\text { Mullen }\end{array}$ & $\begin{array}{l}31 \\
31 \\
30 \\
30\end{array}$ \\
\hline 4 & Jeff Buckley, Grace & Buckley & 28 \\
\hline 5 & Pearl Jam, Ten & $\begin{array}{l}\text { Gossard } \\
\text { Vedder } \\
\text { Ament }\end{array}$ & $\begin{array}{l}25 \\
27 \\
28\end{array}$ \\
\hline
\end{tabular}

Source: Hoye 2003 
Appendix Table 5: Ages at Which Songwriters Wrote Most Important Albums, by Decade, Rolling Stone Rankings

\begin{tabular}{|c|c|c|c|}
\hline Rank & Artist, Album & Writer(s) & Age \\
\hline \multicolumn{4}{|c|}{$\underline{1960 \mathrm{~s}}$} \\
\hline 1 & $\begin{array}{l}\text { Beatles, Sgt. Pepper's Lonely Hearts Club } \\
\text { Band }\end{array}$ & $\begin{array}{l}\text { Lennon } \\
\text { McCartney } \\
\text { Harrison }\end{array}$ & $\begin{array}{l}27 \\
25 \\
24\end{array}$ \\
\hline 2 & Beach Boys, Pet Sounds & $\begin{array}{l}\text { B. Wilson } \\
\text { Asher } \\
\text { Love } \\
\text { Sachen }\end{array}$ & $\begin{array}{l}24 \\
26 \\
25 \\
24\end{array}$ \\
\hline 3 & Beatles, Revolver & $\begin{array}{l}\text { Lennon } \\
\text { McCartney } \\
\text { Harrison }\end{array}$ & $\begin{array}{l}26 \\
24 \\
23\end{array}$ \\
\hline 4 & Bob Dylan, Highway 61 Revisited & Dylan & 24 \\
\hline 5 & Beatles, Rubber Soul & $\begin{array}{l}\text { Lennon } \\
\text { McCartney } \\
\text { Harrison }\end{array}$ & $\begin{array}{l}25 \\
23 \\
22\end{array}$ \\
\hline \multicolumn{4}{|c|}{$\underline{1970 s}$} \\
\hline 1 & Marvin Gaye, What's Going On & $\begin{array}{l}\text { Benson } \\
\text { M. Gaye } \\
\text { Nyx } \\
\text { Stover } \\
\text { A. Gaye }\end{array}$ & $\begin{array}{l}35 \\
32 \\
57 \\
33 \\
49\end{array}$ \\
\hline 2 & Rolling Stones, Exile on Main Street & $\begin{array}{l}\text { Jagger } \\
\text { Richards } \\
\text { Taylor } \\
\text { Harpo }\end{array}$ & $\begin{array}{l}29 \\
29 \\
23 \\
48\end{array}$ \\
\hline 3 & Bob Dylan, Blood on the Tracks & Dylan & 34 \\
\hline 4 & Bruce Springsteen, Born to Run & Springsteen & 26 \\
\hline 5 & John Lennon, Plastic Ono Band & $\begin{array}{l}\text { Lennon } \\
\text { Ono }\end{array}$ & $\begin{array}{l}30 \\
37\end{array}$ \\
\hline \multicolumn{4}{|c|}{$1980 \mathrm{~s}$} \\
\hline 1 & Clash, London Calling & $\begin{array}{l}\text { Jones } \\
\text { Strummer } \\
\text { Taylor } \\
\text { Simonon }\end{array}$ & $\begin{array}{l}25 \\
28 \\
41 \\
24\end{array}$ \\
\hline
\end{tabular}


(Appendix Table 5, continued)

\begin{tabular}{|c|c|c|c|}
\hline 2 & Michael Jackson, Thriller & $\begin{array}{l}\text { Jackson } \\
\text { Temperton } \\
\text { Bettis } \\
\text { Porcaro } \\
\text { Ingram } \\
\text { Jones }\end{array}$ & $\begin{array}{l}24 \\
33 \\
36 \\
25 \\
26 \\
49\end{array}$ \\
\hline 3 & U2, Joshua Tree & $\begin{array}{l}\text { Bono } \\
\text { Clayton } \\
\text { Edge } \\
\text { Mullen }\end{array}$ & $\begin{array}{l}27 \\
27 \\
26 \\
26\end{array}$ \\
\hline 4 & Bob Marley and the Wailers, Legend & $\begin{array}{l}\text { Marley } \\
\text { Tosh } \\
\text { Mayfield }\end{array}$ & $\begin{array}{l}39 \\
40 \\
42\end{array}$ \\
\hline 5 & $\begin{array}{l}\text { Public Enemy, It Takes a Nation of Millions } \\
\text { to Hold Us Back }\end{array}$ & $\begin{array}{l}\text { Chuck D } \\
\text { Sadler } \\
\text { Flavor Flav } \\
\text { Rodgers } \\
\text { Griffin }\end{array}$ & $\begin{array}{l}28 \\
27 \\
29 \\
22 \\
28\end{array}$ \\
\hline \multicolumn{4}{|c|}{$\underline{1990 \mathrm{~s}}$} \\
\hline 1 & Nirvana, Nevermind & $\begin{array}{l}\text { Cobain } \\
\text { Grohl } \\
\text { Novoselic }\end{array}$ & $\begin{array}{l}24 \\
22 \\
26\end{array}$ \\
\hline 2 & U2, Achtung Baby & $\begin{array}{l}\text { Bono } \\
\text { Clayton } \\
\text { Edge } \\
\text { Mullen }\end{array}$ & $\begin{array}{l}31 \\
31 \\
30 \\
30\end{array}$ \\
\hline 3 & Radiohead, The Bends & $\begin{array}{l}\text { J. Greenwood } \\
\text { C. Greenwood } \\
\text { O’Brien } \\
\text { Selway } \\
\text { Yorke }\end{array}$ & $\begin{array}{l}24 \\
26 \\
27 \\
28 \\
27\end{array}$ \\
\hline 4 & The Notorious B. I. G., Ready to Die & B.I.G. & 22 \\
\hline 5 & Pavement, Slanted and Enchanted & Malkmus & 26 \\
\hline
\end{tabular}

Source: Levy 2005. 